\title{
Utility of PCR for \\ DNA Analysis from \\ Dried Blood Spots on Filter Paper Blotters
}

\author{
Edward R.B. McCabe \\ Institute for Molecular Genetics and Department of Pediatrics, \\ Baylor College of Medicine, Houston, Texas 77030
}

$\mathbf{T}_{\mathrm{h}}$ he collection of dried blood spots on filter paper blotters is a major innovation and has facilitated the development and dissemination of newborn screening programs principally because of the ease of sample collection, handling, and shipment to centrally located laboratories and the stability of the analytes in these specimens. ${ }^{(1,2)}$ These samples, which are also known as "Guthrie spots," after their originator Dr. Robert Guthrie, have been used for a considerable number and a broad variety of screening tests. Examples of these tests are shown in Table 1, organized according to newborn screening detection categories. The traditional analyte categories that have been targeted by newborn screening programs have been metabolites, hormones, and proteins (Table 1). ${ }^{(2,3)}$

This report will show that DNA represents a new analyte category for direct mutation detection from these Guthrie spots. In addition to describing how analysis of polymerase chain reaction (PCR)-amplified DNA is beginning to interface with neonatal screening programs, we will discuss the use of dried blood specimens for determination of mutant allele frequencies in various populations, as well as for forensic identification and databases, infectious disease diagnosis, and large animal agriculture. The ability of this PCR-based molecular genetic technology to provide large-scale screening and diagnosis will require the development of automation to reduce the number of personnel needed, and we also will consider current and future developments in this area.

In 1987 it was reported that DNA could be obtained from the dried blood specimens on filter paper blotters. ${ }^{(4)}$ The initial efforts resulted in microextraction of approximately $500 \mathrm{ng}$ of DNA from a single $1 / 2$-in-diameter specimen circle representing the dried equivalent of approximately $50 \mu \mathrm{l}$ of whole blood. This amount of DNA was sufficient for a single Southern blot analysis, but DNA in these amounts was approaching the limits of the existing technology. Fortunately, as these original investigations were being completed, the technique of PCR amplification was reported, ${ }^{(5)}$ and it was shown that the DNA obtained from the dried blood spots could be amplified by PCR. ${ }^{(6)}$ Improvements in the microextraction technique permitted isolation of DNA from as little as a $1 / 8$-indiameter punched disc, representing the dried equivalent of approximately $3 \mu \mathrm{l}$ of whole blood. ${ }^{(6)}$ The develop- ment of the heat-stable polymerase from Thermus aquaticus ${ }^{(7)}$ and a programmable heating block ${ }^{(8)}$ permitted automated temperature cycling to replace the previously tedious manual PCR procedures.

\section{APPLICATION OF PCR AMPLIFICATION IN NEWBORN SCREENING PROGRAMS}

We now will describe how PCR-based DNA diagnosis is interfacing with newborn screening programs for the hemoglobinopathies, Duchenne muscular dystrophy (DMD), and cystic fibrosis (CF).

\section{Hemoglobinopathies}

There is a clear rationale for neonatal hemoglobinopathy screening linked to effective confirmatory testing and clinical follow-up. In 1986, results were

TABLE 1 Newborn Screening Detection Categories

\begin{tabular}{|c|c|c|}
\hline Category & Abnormal analyte(s) & Disease \\
\hline \multicolumn{3}{|l|}{ Metabolites } \\
\hline Plasma & phenylalanine & PKU \\
\hline Red cells & $\begin{array}{l}\text { galactose } \\
\text { galactose 1-phosphate }\end{array}$ & galactosemia \\
\hline \multicolumn{3}{|l|}{ Hormones } \\
\hline Plasma & $\begin{array}{l}\text { T4 and/or TSH } \\
\text { 17-hydroxyprogesterone }\end{array}$ & $\begin{array}{l}\text { congenital hypothyroidism } \\
\text { congenital adrenal hyperplasia }\end{array}$ \\
\hline \multicolumn{3}{|l|}{ Proteins } \\
\hline Plasma & immunoreactive trypsinogen & cystic fibrosis \\
\hline Red cells & $\begin{array}{l}\text { hemoglobin } \\
\text { galactose 1-phosphate } \\
\text { uridyl transferase }\end{array}$ & $\begin{array}{l}\text { hemoglobinopathies } \\
\text { galactosemia }\end{array}$ \\
\hline \multicolumn{3}{|l|}{ DNA } \\
\hline Nucleated cells & DNA & $\begin{array}{l}\text { hemoglobinopathies, Duchenne } \\
\text { muscular dystrophy, cystic fibrosis, } \\
\text { and other diseases with defined } \\
\text { mutations }\end{array}$ \\
\hline
\end{tabular}


presented from a collaborative, randomized trial of penicillin prophylaxis that demonstrated the need for newborn screening for the purpose of early identification and treatment of patients with sickle cell disease. ${ }^{(9)}$ There was an $84 \%$ reduction in the incidence of infection in the treated group, and although there were no deaths from pneumococcal sepsis among the treated children, there were three deaths in the placebo group. These investigators concluded that children should be screened for sickle cell disease, and those with sickle cell disease should begin penicillin prophylaxis by 4 months of age. Subsequently, a National Institutes of Health (NIH) consensus development conference recommended that universal neonatal screening should be adopted for the hemoglobinopathies to prevent early death from septicemia among children with sickle cell disease. ${ }^{(10)}$

Primary screening for these disorders has relied on detection of the hemoglobin protein phenotype. ${ }^{(11,12)}$ The protocols in many hemoglobinopathy screening programs have recommended repeat analysis at 2-4 months of age when the proportion of hemoglobin $F$ would be diminished, so that the adult $\beta$-globin phenotype could be determined more easily. Since molecular genetic methods would not be influenced by the developmental expression of the hemoglobins, it was logical that direct genotypic analysis from the original filter paper specimen would have the potential to facilitate the diagnostic confirmation of patients with sickle cell disease, thus providing more efficient diagnosis and efficacious management. ${ }^{(6)}$

It was demonstrated that DNA could be obtained from Guthrie spots by microextraction ${ }^{(4,6,13)}$ or boiling, ${ }^{(6)}$ and that this DNA could be analyzed for the $A$ and $S$ alleles after PCR amplification. ${ }^{(6,13,14)}$ More recently, a blinded molecular genetic analysis of 75 specimens from the Texas Department of Health Newborn Screening Laboratory compared the results from DNA analysis with the hemoglobin phenotype determined by electrophoresis in the state screening laboratory. ${ }^{(15)}$ DNA was extracted from a $1 / 2$-in semicircle representing the dried equivalent of approximately 25 $\mu \mathrm{l}$ of whole blood. The microextraction procedure used in this study was similar to that previously described, ${ }^{(6)}$ with the exception that the proteinase $\mathrm{K}$ digestion proceeded overnight (see Protocol 1). This procedure resulted in improved yields of DNA. From 75 specimens, each representing approximately $25 \mu \mathrm{l}$ of dried whole blood equivalent, the range of $\mathrm{DNA}$ recovered by microextraction was $900-2000$ $\mathrm{ng}$, with a median of $1500 \mathrm{ng} / \mathrm{semi}$ circle.
Four molecular genetic techniques were used to analyze the PCR-amplified products from each specimen. These techniques included hybridization with allele-specific oligonucleotide (ASO) probes labeled with ${ }^{32} \mathrm{p}$ or horseradish peroxidase (HRP), direct digestion with the restriction enzyme Ddel, and Southern blot analysis using ${ }^{32} \mathrm{p}$-labeled ASO probes. Of these 75 samples, there were disagreements between the DNA results and the hemoglobin phenotypes in five specimens. Two specimens disagreed on all four

\section{PROTOCOL 1: DNA MICROEXTRACTION FROM DRIED BLOOD SPECIMENS ON FILTER PAPER BLOTTERS}

1. Cut out one-fourth of a 1/2-in-diameter circle of dried blood. Wash scissors between samples with $0.3 \times \mathrm{HCl}$ for $5 \mathrm{~min}$, rinse with deionized $\mathrm{H}_{2} \mathrm{O}$, and dry with paper tissues.

2. Cut the quarter circle into small pieces and place into a $1.5-\mathrm{ml}$ sterile microfuge tube.

3. Cover the sample with methanol for 5-15 $\mathrm{min}$.

4. Speed vac to dryness.

5. Add $380 \mu \mathrm{l}$ of $0.15 \mathrm{M} \mathrm{NaCl} / \mathrm{O} .5 \%$ SDS and incubate in a $37^{\circ} \mathrm{C}$ bath for $2 \mathrm{hr}$.

6. Add proteinase $\mathrm{K}(50 \mu \mathrm{g})$, and incubate for $1-2 \mathrm{hr}$ (or overnight) in $37^{\circ} \mathrm{C}$ bath (overnight digestion may produce better yield).

7. Transfer liquid and rinse paper twice with $100 \mu \mathrm{l}$ of $0.15 \mathrm{M} \mathrm{NaCl} / 0.5 \%$ SDS each. Place total volume in a new $1.5-\mathrm{ml}$ microfuge tube.

8. Extract with an equal volume of buffered phenol.

9. Extract with buffered phenol ( $1 / 2$ volume) and chloroform/isoamyl alcohol (24:1) (1/2 volume); i.e., if sample volume is $500 \mu \mathrm{l}$, add $250 \mu \mathrm{l}$ of phenol and $250 \mu \mathrm{l}$ of chloroform/isoamyl alcohol (24:1) and perform extraction.

10. Extract with an equal volume of chloroform/isoamyl alcohol (24:1).

11. Add $2.5 x$ volume of $100 \%$ absolute alcohol (kept in $-20^{\circ} \mathrm{C}$ freezer) and add $10 \%$ volume of $3 \mathrm{M} \mathrm{NaAc}(\mathrm{pH} \mathrm{5.2)}$.

12. Place in $-20^{\circ} \mathrm{C}$ freezer overnight or in $-70^{\circ} \mathrm{C}$ freezer for $1-2 \mathrm{hr}$.

13. Centrifuge $10-15 \mathrm{~min}$ (14,000 rpm); discard liquid.

14. Add volume from step 8 of $75 \%$ ethanol and centrifuge again for $10-15 \mathrm{~min}$.

15. Let air-dry.

16. Add $100 \mu \mathrm{l} \mathrm{TE}$ buffer and evaluate DNA by running $10 \%$ of the total volume on a $1 \%$ ME agarose gel.

Comment: This protocol is an updated version of the previously described microextraction method. ${ }^{(6,15)}$ Washing the scissors in $0.3 \mathrm{~N} \mathrm{HCl}$ is intended to depurinate the DNA and prevent cross-contamination by carry-over between specimens. ${ }^{(6)}$ Methanol fixation (steps 3-4) is a standard procedure in neonatal screening to prevent diffusion of hemoglobin from the filter paper matrix, and was introduced in this procedure ${ }^{(6)}$ to prevent inhibition of the PCR reaction by an inhibitor found in whole blood. In our hands, the success of PCR amplification from dried blood specimens is improved by methanol fixation. 
DNA methods after the first extraction, but agreed after extraction of the second semicircle of the original spot received in the DNA laboratory; this discrepancy was presumed to be due to contamination during PCR. A third sample disagreed on only one of the four analyses, and, upon repeat, agreed with the state laboratory on all four; this was presumed due to contamination after PCR. Only two of the 75 samples showed disagreements between the state and the DNA laboratories that were not resolved by extraction of the second half of the original spot, and a repeat specimen from the patient would have been required. On one of these, there was poor amplification initially; no amplification could be obtained with a second blood spot from the initial blotter, and it was concluded that this sample was of inadequate quality for amplification. A second sample also showed consistent disagreement between the two laboratories: The hemoglobin phenotype was FS, whereas the genotype was determined to be AS by all four tests on four different sets of analyses using two different spots from the original blotter. This discrepancy was explained when clinical evaluation determined that the patient had $S / \beta$ thalassemia. This study showed DNA confirmation would reduce by $97 \%$ the need for, and costs of, a second specimen for diagnosis.

We are now using molecular genetic analysis of PCR-amplified DNA for the confirmation of positive newborn screening tests in Texas and for the clarification of those that are inconclusive by hemoglobin electrophoresis. We have developed methods for evaluating the A, S, C, and E alleles using direct amplification without microextraction, a system that provides a remarkable reduction in the number of personnel needed and the expense ${ }^{(15)}$ (see final section on Automation and Protocol 2). We have proposed an ethnicity-based algorithm to identify the most common $\beta$-thalassemia alleles, accounting for $80-90 \%$ of this disorder among African-American, Asian Indian, Chinese/southeast Asian, and Mediterranean individuals. ${ }^{(15)}$

\section{Duchenne Muscular Dystrophy}

$\mathrm{DMD}$ is an $\mathrm{X}$-linked recessive disease

\section{PROTOCOL 2: DIRECT AMPLIFICATION OF DNA FROM DRIED BLOOD SPECIMENS ON FILTER PAPER BLOTTERS}

1. Cut a $4 \times 4-\mathrm{mm}$ square from dried blood spot. Place the square in $1.5-\mathrm{ml} \mathrm{mi}-$ crofuge tube. Wash scissors between specimens as described in step 1 in Protocol 1.

2. Methanol-fix as in steps 3-4 of Protocol 1.

3. Add all PCR reaction components (water, dNTPs, primers, buffer) with the exception of Taq polymerase.

4. Heat for $10-15 \mathrm{~min}$ at $95-97^{\circ} \mathrm{C}$.

5. Add Taq polymerase at 2.5 units/tube (to bring to a total volume of $100 \mu \mathrm{l}$ ).

6. Start the PCR reaction and run for 30-35 cycles. The following is a typical cycle we use for $\beta$-globin amplification: denaturation $94^{\circ} \mathrm{C}$ for $30 \mathrm{sec}$; annealing $55^{\circ} \mathrm{C}$ for $30 \mathrm{sec}$; and extension $72^{\circ} \mathrm{C}$ for $1 \mathrm{~min}$.

Comment: This procedure for direct amplification was adapted from that of Schwartz et al. ${ }^{(61)}$ as described by Descartes et al. ${ }^{(15)}$ This procedure has been more reliable than the boiling of methanol-fixed specimens in our hands. ${ }^{(6)}$ We tried a variety of sizes of specimens and determined optimal amplification with the $4 \times 4$ $\mathrm{mm}$ size. Similarly, although amplification is achieved if Taq polymerase is added with the other components (step 3), we have found improved yields if we add this component in step 5 after the initial heat step (step 4).

with an estimated incidence of 1:3000 to $1: 5000$ male live births. ${ }^{(16)}$ Because of progressive muscle deterioration, these patients become wheelchair bound by $12-15$ years of age; death occurs in the second or third decade of life. Newborn screening programs have measured blood creatine kinase (CK) enzymatic activity in dried blood specimens.

Probes derived from the $14-\mathrm{kb}$ DMD cDNA $^{(17)}$ can be used for Southern blot analysis of DNA from patients with this disorder. These DMD cDNA probes detect deletions in approximately $56 \%$ of patients with DMD. ${ }^{(18)}$ The patients' deletions are not distributed uniformly throughout the DMD genomic region, but rather there are definite deletion "hotspots." $(17,18)$ Multiplex PCR, targeting the regions with the highest frequency of deletions, can detect approximately $80-90 \%$ of the deletions in these patients using nine sets of PCR primers. ${ }^{(19,20)}$ Thus, nearly $50 \%$ of all patients with DMD can be detected by multiplex PCR. This "nine-plex" PCR procedure greatly facilitates the diagnosis of these patients, reducing the need for more labor intensive Southern blotting.
Our group and others have been able to perform multiplex PCR on DNA obtained from dried blood specimens by microextraction, with excellent results. ${ }^{(21,22)}$ Direct amplification has proven sufficiently robust to permit nine-plex PCR from neonatal screening blotters without microextraction. (23) Multiplex PCR would facilitate rapid genotypic confirmation from the original blood specimen in newborn screening programs for DMD, eliminating the need for repeat specimens in approximately $50 \%$ of the true positives identified by an initial positive screening test. Naylor and his group in Pittsburgh have incorporated multiplex PCR analysis into their DMD newborn screening program. ${ }^{(22)}$

\section{Cystic Fibrosis}

$\mathrm{CF}$ is an autosomal recessive disorder with a frequency among Caucasians of approximately $1: 2000$ live births. ${ }^{(16)}$ The gene for CF, which maps to $7 q 31$, has been cloned and is referred to as the CF transmembrane conductance receptor (CFTR). ${ }^{(24-26)}$ The CFTR CDNA predicts a polypeptide sequence 1480 amino acids in length with a molecular mass of $168 \mathrm{kD} .^{(25)}$ It has structural characteristics that are very similar to 
the mammalian multidrug-resistance P-glycoproteins, consistent with involvement in membrane transport. The CFTR has two repeated motifs, both of which contain putative membrane-spanning domains and sequences suggestive of consensus nucleotide (ATP) binding folds (NBFs). The CFTR can infer chloride channel function on cultured CF cells previously deficient in these channels. ${ }^{(27,28)}$

The most common mutant allele among Caucasians is a deletion of $3 \mathrm{bp}$ in the first NBF resulting in the inframe deletion of amino acid number 508, a phenylalanine (DeltaF508). ${ }^{(26)}$ PCR amplification and ASO hybridization demonstrated that the DeltaF508 allele was present in $75.8 \%$ of $\mathrm{CF}$ chromosomes, leading to the conclusion that population-based screening would identify approximately $57 \%$ of non-Ashkenazic Caucasian couples at risk for CF. ${ }^{(29)}$ An NIH-sponsored workshop recommended that mutation analysis for the purpose of carrier detection should be carried out in families with a history of $C F$, but that population-based carrier screening was not yet appropriate. ${ }^{(30)}$

The use of newborn screening specimens had been demonstrated for CF haplotype analysis using PCRamplified DNA, even before the cloning of the CFTR gene and the characterization of the DeltaF508 mutation. ${ }^{(31,32)}$ One report showed the remarkable stability of DNA over time in these dried blood specimens. ${ }^{(31)}$ DNA from a Guthrie spot that had been obtained in 1971 was microextracted, amplified, and analyzed in 1988 to permit informed genetic counseling of a sibling whose sister had died with CF. No other source of DNA was available for analysis other than the 17 year-old newborn screening specimen from the proband.

The analysis of the Deltal:508 allele in dried specimens on filter paper has been described using PCR amplification of microextracted $\mathrm{DNA}^{(22,33)}$ and direct amplification without microextraction. $23,33,34)$ PCR amplification followed by polyacrylamide gel electrophoresis (PAGE) for separation of homoduplexes and heteroduplexes(35) may be used in these analyses. $(22,33)$ Assuming that the DeltaF508 allele is present in $75.8 \%$ of CF chromosomes,
$57 \%$ of true positive individuals in a CF newborn screening program would be homozygous for DeltaF508, 37\% would be mixed heterozygotes with one DeltaF508 allele, and 6\% of CF individuals would not be detected with a test targeted solely for the DeltaF508 mutation. ${ }^{(33)}$

Pilot studies are in progress to determine the efficacy of newborn screening for CF homozygotes based on the measurement of immunoreactive trypsinogen (IRT) in Guthrie spots. ${ }^{(16)}$ The use of direct genotypic analysis for the DeltaF508 mutation on samples from the original blotters with initial elevated IRT could eliminate the need for a follow-up specimen for repeat IRT analysis in over $50 \%$ of true positive $\mathrm{CF}$ individuals ascertained by the initial IRT screen. Therefore, PCR amplification and genotypic analysis on the initial specimen would represent a significant reduction in the cost to a newborn screening program for collection of the repeat specimens and the performance of the confirmatory IRT analyses. Even greater reductions in costs would occur as DNA testing for additional $\mathrm{CF}$ alleles was added to such a program: At an allele detection rate of $95 \%$, direct genotyping would confirm approximately $90 \%$ of true positives on the initial IRT. In addition, the identification of the DeltaF508 and other mutant alleles among CF individuals would facilitate the recommendation of the $\mathrm{NIH}$ workshop concerning molecular genetic evaluation of all individuals with a positive family history of $\mathrm{CF}^{(30)}$ Such a program would immediately identify families amenable to the currently available molecular genetic testing. It must be noted, however, that a program of this type would incidentally identify carrier individuals among those with false-positive newborn screening tests. ${ }^{(33)}$ Again, assuming that the DeltaF508 mutation represents $75.8 \%$ of the $\mathrm{CF}$ alleles, such incidental ascertainment of individuals as carriers for this allele would occur in approximately 1:30 false-positive individuals. For these reasons, any program linking molecular genetic analysis to newborn screening must include genetic counseling as an integral component. It remains to be seen whether dried blood specimens will be used in the large population-based screening programs that eventually will be undertaken for CF carrier detection.

\section{APPLICATIONS OF DRIED BLOOD SPECIMENS FOR PCR BEYOND NEWBORN SCREENING}

Mutant Allele Frequency Ascertainment

Newborn screening programs have provided us with substantial data on the frequency of various diseases in different populations. ${ }^{(16)}$ The technical ability to perform molecular genetic analyses from amplified DNA in a dried blood specimen within a filter paper matrix will permit the Guthrie spots to be used for ascertainment of mutant allele frequencies in any given study population. This approach has the advantage that one need not evaluate the large numbers of homozygous individuals required to have an accurate assessment of disease frequency. The investigator can screen a much smaller sample of specimens, since identification of the frequency of a specific allele among the heterozygotes will provide the desired information on the frequency of homozygotes, compound heterozygotes, and true heterozygotes in the population under study. The stability of DNA in the filter paper sample and the ease of shipment of dried blood specimens to a centralized laboratory will allow the investigation of allele frequencies in populations that may be geographically or culturally isolated ${ }^{(4)}$

Dried blood specimens have been used to evaluate the frequency of specific alleles for several different disorders by PCR analysis. Examples of this approach have included a study of the contribution of Hemoglobin DPunjab $^{(36)}$ and 10 different $\beta$-thalassemia alleles ${ }^{(37)}$ to the hemoglobinopathies in China, and the frequency of a specific allele for phenylketonuria (PKU) among affected patients in Southern Europe and Northern Africa. ${ }^{(38,39)}$ Another example involves medium-chain acyl coenzyme A dehydrogenase (MCAD) deficiency, a disorder characterized by hypoketotic hypoglycemia and significant mortality early in life. ${ }^{(40)}$ A single mutation accounts for approximately $90 \%$ of the mutant alleles for MCAD deficien- 
cy, ${ }^{(41-43)}$ and this allele is detectable after PCR of the DNA in Guthrie spots. $(41,43) \quad$ Neonatal screening specimens from the United Kingdom, Australia, the United States, and Japan were analyzed to determine, in an unbiased manner for the first time, the frequency of MCAD deficiency in these populations. ${ }^{(43,44)}$ It has been established that a similar PCR-based approach would be feasible for determining allele frequencies for hereditary fructose intolerance (HFI) (D.R. Tolan, Boston University, pers. comm.). The value of such information to newborn screening programs and other health care planning activities will undoubtedly lead to many more of these studies in the future.

\section{Forensic Identification and DNA Data Bases}

DNA analysis for forensic purposes or "DNA fingerprinting" has relied on evaluation of dried specimens, such as blood and semen, representing evidence in criminal cases. ${ }^{(4-48)}$ However, there has also been consideration of collection of dried blood specimens on filter paper for developing forensic identification databases.

The stability of DNA in neonatal screening blotters would make these specimens a potential resource for purposes of identification. In fact, an inquiry regarding retrieval of a newborn specimen for forensic identification has been received in one state (G. Cunningham, California Department of Health, pers. comm.). The practice in the United States of discarding neonatal screening specimens in many states after a certain interval will limit the use of such samples for forensic identification.

The U.S. military has begun to consider the formalized use of dried blood spots on filter paper blotters as a means of cataloging DNA should it be required for casualty identification $(\mathrm{V}$. Weeden, Armed Forces Institute of Pathology, pers. comm.). One proposed plan would include two filter paper blotters from all uniformed personnel, one to be stored, desiccated, and frozen, and the other to be placed in the individual's file. A buccal swab $^{(49)}$ placed in alcohol would also be collected from each person. The stored specimens would be analyzed only if the necessity should arise. This program has been referred to as the "DNA dog tag."

Although states have begun to collect DNA for genotyping from convicted felons, particularly sex offenders, ${ }^{(50,51)}$ it is unclear that any of these database programs involve filter paper storage. However, at least one health insurance company has begun to collect blood in filter paper blotters as part of intake processing (G.P. Oakley, Centers for Disease Control, pers. comm.). A number of issues have been raised regarding expectations of privacy and confidentiality, linkage of databases, and potential misuse or abuse of DNA information by law enforcement agencies and commercial insurers. ${ }^{(50-53)}$

\section{Infectious Disease}

The specificity of PCR will have major advantages for diagnosis of infectious agents. ${ }^{(54-56)}$ Primers designed for amplification of pathogen DNA will permit rapid identification of individual species or strains. The sensitivity of PCR is valuable in disorders associated with a low concentration of the agent in blood or other body fluids (e.g., HIV). However, for other diseases this level of sensitivity may detect pathogen DNA in persons without clinical features.

Whole-blood filtrates collected on filter paper have been used for PCR amplification and diagnosis of malaria. ${ }^{(5)}$ Among the considerations in developing this diagnostic strategy was the cost of the methods, since many of the Third World countries afflicted with these parasites have low health care budgets (D. Wirth, Harvard School of Public Health, pers. comm.). Also important is the ability to perform testing in the field, since it is optimal to identify affected individuals in their own locales. Wirth and colleagues have found that collection of filtrates from small blood samples on blotters is inexpensive, can be performed easily in the field by relatively inexperienced individuals, and is acceptable among cultures in which the members would avoid collection of larger volumes of blood. Amplification and diagnosis can be carried out inexpensively with the estimated cost per specimen for local labor and reagents in a country such as Thailand being comparable to the cost of treating a patient. Therefore, this PCR-based approach will make it economically feasible to screen population groups for those with a clinically significant parasite burden, rather than treating the entire group with the attendant risks of untoward reactions. The stability of the DNA on these filter paper specimens also permits transportation to distant laboratories for evaluation of field performance. This blotter-based amplification program for malaria diagnosis represents an intriguing paradigm for effective technology transfer to treat large numbers of individuals.

\section{Agricultural Applications}

Inbred populations of agricultural animals may manifest inherited diseases at much higher than expected rates due to the concentration of rare recessive mutations from a limited number of foundation stock. These disorders represent significant economic burdens to those involved in the husbandry of these breeds. A genetic strategy, such as exclusion of heterozygote males from the breeding stock, can eliminate homozygotes.

Healy and colleagues have shown that blood specimens on filter paper blotters can be used for DNA amplification and heterozygote screening to identify citrullinemia carriers among dairy cattle in Australia (P.J. Healy, Elizabeth Macarthur Agricultural Institute, New South Wales, pers. comm.). A C-T transition in argininosuccinate synthetase results in conversion of arginine-86 (CGA) to a nonsense (TGA) codon and this can be detected by loss of an Avall site in the mutant allele. ${ }^{(58)}$ Calves with this disorder develop hyperammonemia, depression, and convulsions, and die within the first week of life. ${ }^{(59)}$ Direct digestion of PCRamplified, microextracted DNA from blood spots collected on filter paper blotters has the potential for facilitating rapid and economical ascertainment of heterozygotes, with screening efforts primarily targeting males who would be potential breeding stock.

\section{AUTOMATION: KEY TO FUTURE DEVELOPMENT}

The large-scale application of DNA technology for genetic screening to detect heterozygotes or homozygotes, 
or for diagnosis of infectious diseases, will require decreased personnel intensity and increased automation of PCR-based methods. ${ }^{(60)}$ Approaches are being developed that will facilitate broader application of DNA diagnosis using dried blood spots.

Schwartz et al. have shown that small aliquots of dried blood specimens can be introduced directly into PCR reaction mixtures for direct amplification without microextraction. ${ }^{(61)}$ This procedure involves an initial heat step that can be programmed into the automated thermal cyclers ${ }^{(8)}$ as an initial command in the routine amplification protocol. They used $T$. thermophilus polymerase and found that this enzyme was sufficiently stable that it could be included in the reaction mix prior to addition of the blood specimen. Our experience with $T$. aquaticus (Taq) polymerase has indicated that it is preferable to add the enzyme after the specimen has been heated initially in the reaction buffer. ${ }^{(15,23)}$ Direct PCR amplification from dried blood samples has been accomplished successfully for the hemoglobinopathies, ${ }^{(15,23)} \mathrm{DMD},{ }^{(23)} \mathrm{CF},(33,34)$ and phenylketonuria. ${ }^{(61)}$ The consequence has been a marked reduction in the number of personnel required for blotter-based amplification.

Improved efficiency and sample throughput will also be required for the analytical techniques to accommodate large-scale applications. Automated direct sequencing after asymmetric PCR would be one possible approach. We have demonstrated that DNA microextracted from dried blood specimens can be amplified and utilized for direct sequencing of $\beta$-globin alleles using the ABI automated DNA sequencer. ${ }^{(15)}$ As a consequence of the activities within the Human Genome Initiative, this technology will become increasingly more efficient and less expensive. The use of fluorescent primers and a competitive oligonucleotide priming (COP) strategy ${ }^{(62)}$ permits automated analysis of the products and has been demonstrated to be yet another potential approach to decrease personnel time and increase sample throughput. ${ }^{63)}$

Robotic interfacing of direct PCR amplification with analysis will be facilitated by the development of solid- phase, non-gel-based allele detection technology. Robotic workstations have been designed that include the heat cycling required for $\mathrm{PCR}$ amplification, accommodate microtiter plates, and can be adapted for optical plate reading. ${ }^{(64)}$ The use of double-stranded DNA binding proteins that can be genetically engineered to bind to polystyrene offers one intriguing approach for the development of solidphase assay systems. ${ }^{(65)}$ Automated sequence detection has been described using PCR amplification, followed by an ELISA-based colorimetric oligonucleotide ligation assay (OLA). ${ }^{(66)}$ Punch-index machines can automatically deliver punched circles from filter paper blotters to specified wells in $\mathrm{mi}$ crotiter plates. ${ }^{(2)}$ Innovation in developing and adapting PCR-based automated approaches will be required for any large-scale application of DNA technology, but all of the necessary components currently are available for the initial efforts using Guthrie spots.

\section{ACKNOWLEDGMENTS}

This work was supported by grants from the Bureau of Maternal and Child Health and Resources Development, Division of Services for Children with Special Health Needs (MCJ-480566 and MCJ-009121).

\section{REFERENCES}

1. Guthrie, R. and A. Susi. 1963. A simple phenylalanine method for detecting phenylketonuria in large populations of newborn infants. Pediatrics 32: 338-343.

2. Guthrie, R. 1980 Organization of a regional newborn screening laboratory. In Neonatal screening for inborn errors of metabolism (ed. H. Bickel, R. Guthrie, and G. Hammersen), pp. 259-270, Springer, Berlin.

3. McCabe, E.R.B. and L. McCabe. 1983. Screening for PKU in sick or premature neonates. I. Pediatr. 103: 502--503.

4. McCabe, E.R.B., S.-Z. Huang, W.K. Seltzer, and M.L. Law. 1987. DNA microextraction from dried blood spots on filter paper blotters: Potential applications to newborn screening. Hum. Genet. 75: 213-216.

5. Saiki, R.K., S. Scharf, F. Faloona, K.B. Mullis, G.T. Horn, H.A. Erlich, and N. Arnheim. 1985. Enzymatic amplifica- tion of $\beta$-globin genomic sequences and restriction site analysis for diagnosis of sickle cell anemia. Science 230: 1350-1354.

6. Jinks, D.C., M. Minter, D.A. Tarver, M. Vanderford, J.F. Hejtmancik, and E.R.B. McCabe. 1989. Molecular genetic diagnosis of sickle cell disease using dried blood specimens on blotters used for newborn screening. Hum. Genet. 81: 363-366.

7. Saiki, R.K., D.H. Gelfand, S. Stoffel, S.J. Scharf, R. Higuchi, G.T. Horn, K.B. Mullis, and H.A. Erlich. 1988. Primer-directed enzymatic amplification of DNA with a thermostable DNA poly-merase. Science 239: 487-491.

8. Oste, C. 1989. PCR automation. In PCR technology-Principles and applications for DNA amplification (ed. H.A. Erlich), pp. 23-30. Stockton Press, New York.

9. Gaston, M.H., J.I. Vetter, G. Woods, et al. 1986. Prophylaxis with oral penicillin in children with sickle cell anemia-A randomized trial. N. Engl. J. Med. 314: 1593-1599.

10. Wethers, D.L. and Panel. 1987. Newborn screening for sickle cell disease and other hemoglobinopathies. National Institutes of Health Consensus Development Conference Statement 6(9): 1-22.

11. Schneider, R.G. 1986. Laboratory identification of hemoglobin variants in the newborn. In Genetic disease-Screening and management (ed. T.P. Carter and A.M. Willey), pp. 137-150. Liss, New York.

12. Garrick, M.D. 1987. Technical options for screening newborns for hemoglobinopathies. In Advances in neonatal screening (ed. B.L. Therrell), pp. 417-423. Elsevier, Amsterdam.

13. Rubin, E.M., K.A. Andrews, and Y.W. Kan. 1989. Newborn screening by DNA analysis of dried blood spots. Hum. Genet. 82: 134-136.

14. McCabe, E.R.B., Y.-H. Zhang, M. Descartes, B.L. Therrell, and H.A. Erlich. 1989. Rapid detection of beta $S$ DNA from Guthrie cards by chromogenic probes. Lancet ii: 741 .

15. Descartes, M., Y. Huang, Y.-H. Zhang, L. McCabe, R. Gibbs, B.L. Therrell, and E.R.B. McCabe, personal communication.

16. Committee on Genetics, American Academy of Pediatrics. 1989. 
Newborn screening fact sheets. Pediatrics 83: 449-464.

17. Koenig, M., E.P. Hoffman, C.J. Bertelson, A.P. Monaco, C. Feener, and L.M. Kunkel. 1987. Complete cloning of the Duchenne muscular dystrophy (DMD) cDNA and preliminary genomic organization of the DMD gene in normal and affected individuals. Cell 50: 509-517.

18. Baumbach, L.L., J.S. Chamberlain, P.A. Ward, N.J. Farwell, and C.T. Caskey. 1989. Molecular and clinical correlations of deletions leading to Duchenne and Becker muscular dystrophies. Neurology 39: 465-474.

19. Chamberlain,, J.S., R.A. Gibbs, J.E. Ranier, P.N. Nguyen, and C.T. Caskey. 1988. Deletion screening of the Duchenne muscular dystrophy locus via multiplex amplification. Nucleic Acids Res. 16: 11141-11156.

20. Chamberlain, J.S., R.A. Gibbs, J.E. Ranier, and C.T. Caskey. 1990. Multiplex PCR for the diagnosis of Duchenne muscular dystrophy. In PCR protocols $-A$ guide to methods and applications (ed. M.A. Innis, D.H. Gelfand, J.J. Sninsky, and T.J. White), pp. 272-281. Academic Press, New York.

21. McCabe, E.R.B., Y. Huang, M. Descartes, Y.-H. Zhang, and R.G. Fenwick. 1990. DNA from Guthrie spots for diagnosis of DMD by multiplex PCR. Biochem. Med. Metab. Biol. 44: 294-295.

22. Naylor, E. 1991. New technologies in newborn screening. Yale J. Biol. Med. 64: $21-24$.

23. Descartes, M., Y. Huang, Y.-H. Zhang, L.L. McCabe, R.G. Fenwick, B.L. Therrell, W.K. Seltzer, and E.R.B. McCabe. 1991. Direct amplification without microextraction facilitates molecular genetic analysis of neonatal screening specimens. Proceedings of the Eighth International Neonatal Screening Symposium. (In press.)

24. Rommens, J.M., M.C. Iannuzzi, B. Kerem, M.L. Drumm, G. Melmer, M. Dean, R. Rozmahel, J.L. Cole, D. Kennedy, N. Hidaka, M. Zsiga, M. Buchwald, J.R. Riordan, L.-C. Tsui, and F.S. Collins. 1989. Identification of the cystic fibrosis gene: Chromosome walking and jumping. Science 245: 1059-1065.
25. Riordan, J.R., J.M. Rommens, B. Kerem, N. Alon, R. Rozmahel, Z. Grzelczak, J. Zielenski, S. Lok, N. Plavsic, J.-L. Chou, M.L. Drumm, M.C. Iannuzzi, F.S. Collins, and L.-C. Tsui. 1989. Identification of the cystic fibrosis gene: Cloning and characterization of complementary DNA. Science 245: 1066-1073.

26. Kerem, B., J.M. Rommens, J.A. Buchanan, D. Markiewicz, T.K. Cox, A. Chakravarti, M. Buchwald, and L.C. Tsui. 1989. Identification of the cystic fibrosis gene: Genetic analysis. Science 245: 1073-1080.

27. Drumm, M.L., H.A. Pope, W.H. Cliff, J.M. Rommens, S.A. Marvin, R.A. Frizzell, and J.M. Wilson. 1990. Correction of the cystic fibrosis defect in vitro by retrovirus-mediated gene transfer. Cell 62: 1227-1233.

28. Rich, D.P., M.P. Anderson, R.J. Gregory, S.H. Cheng, S. Paul, D.M. Jefferson, J.D. McCann, K.W. Klinger, A.E. Smith, and M.J. Welsh. 1990. Expression of cystic fibrosis transmembrane conductance regulator corrects defective chloride channel regulation in cystic fibrosis airway epithelial cells. Nature 247: 358-363.

29. Lemna, W.K., G.L. Feldman, B. Kerem, S.D. Fernbach, E.P. Zerkovich, W.E. O'Brien, J.R. Riordan, F.S. Collins, L.-C. Tsui, and A.L. Beaudet. 1990. Mutation analysis for heterozygote detection and the prenatal diagnosis of cystic fibrosis. N. Engl. J. Med. 322: 291-296.

30. Beaudet, A.L., H.H. Kazazian, Panel. 1990. Statement from the $\mathrm{NIH}$ workshop on population screening for the cystic fibrosis gene. March 6 , 1990. N. Engl. J. Med. 323: 70-71.

31. Williams, C., L. Weber, R. Williamson, and M. Hjelm. 1988. Guthrie spots for DNA-based carrier testing in cystic fibrosis. Lancet ii: 693.

32. McIntosh, I., L. Strain, and D.J.H. Brock. 1988. Prenatal diagnosis of cystic fibrosis where single affected child has died: Guthrie spots and microvillar enzyme testing. Lancet ii: 1085.

33. Seltzer, W.K., F. Accurso, M.Z. Fall, A. Van Riper, M. Descartes, Y. Huang, and E.R.B. McCabe. 1991. Screening for cystic fibrosis: Feasibility of molecular genetic analysis of dried blood specimens. Biochem. Med. Metab. Biol. 46: 105-109.
34. Nelson, P.V., W.F. Carey, and C.P. Morris. 1990. Gene amplification directly from Guthrie blood spots. Lancet ii: 1451-1452.

35. Rommens, J., B.-S. Kerem, W. Greer, P. Chang, L.-C. Tsui, and P. Ray. 1990. Rapid nonradioactive detection of the major cystic fibrosis mutation. Am. J. Hum. Genet. 46: 395-396.

36. Zeng, Y.-T., S.-Z. Huang, Z.-R. Ren, and H.-J. Li. 1989. Identification of Hb D-Punjab gene: Application of DNA amplification in the study of abnormal hemoglobins. Am. J. Hum. Genet. 44: 886-889.

37. Huang, S., X. Zhou, Z. Ren, and Y. Zeng. 1990. Detection of $\beta$-thalassemia mutations in the Chinese using amplified DNA from dried blood specimens. Hum. Genet. 84: 129-131.

38. Lyonnet, S., C. Caillaud, F. Rey, M. Berthelon, J. Frezal, J. Rey, and A. Munnich. 1988. Guthrie cards for detection of point mutations in phenylketonuria. Lancet ii: $5 \mathrm{O} 7$.

39. Lyonnet, S., C. Caillaud, F. Rey, M. Berthelon, J. Frezal, J. Rey, and A. Munnich. 1989. Molecular genetics of phenylketonuria in Mediterranean countries: A mutation associated with partial phenylalanine hydroxylase deficiency. Am. J. Hum. Genet. 44: 511-517.

40. Roe, C.R. and P.M. Coates. 1989. Acyl-CoA dehydrogenase deficiencies. In The metabolic basis of inherited disease (ed. C.R. Scriver, A.L. Beaudet, W.S. Sly, and D. Valle), pp. 889-914. McGraw Hill, New York.

41. Matsubara, Y., K. Narisawa, S. Miyabayashi, K. Tada, and P.M. Coates. 1990. Molecular lesion in patients with medium chain acylCoA dehydrogenase deficiency. Lancet i: 1589.

42. Yokota, I., Y. Indo, P.M. Coates, and K. Tanaka. 1990. Molecular basis of medium chain acyl-coenzyme A dehydrogenase deficiency. J. Clin. Invest. 86: 1000-1003.

43. Matsubara, Y., K. Narisawa, K. Tada, H. Ikeda, Y. Ye-Qi, D.M. Danks, A. Green, and E.R.B. McCabe. 1991. Prevalence of the most common mutation in the medium-chain acylCoA dehydrogenase gene determined from Guthrie cards. Lancet 338: 552-553.

44. Blakemore, A.I.F., H. Singleton, R.J. Pollit, P.C. Engel, S. Kelvraa, N. 
Gregersen, and D. Curtis. 1991. Frequency of the G985 MCAD mutation in the general population. Lancet 337: 298-299.

45. Jeffreys, A.J., V. Wilson, and S.L. Thein. 1985. Hypervariable "minisatellite" regions in human DNA. Nature 314: 67-73.

46. Jeffreys, A.J., V. Wilson, and S.L. Thein. 1985. Individual-specific "fingerprints" of human DNA. Nature 316: 76-79.

47. Ballantyne, J., G. Sensabaugh, and J. Witkowski, ed. 1989. DNA technology and forensic science. Cold Spring Harbor Laboratory Press, New York.

48. Kirby, L.T. 1990. DNA fingerprinting-An introduction. Stockton Press, New York.

49. Lench, N., P. Stanier, and R. Williamson. 1988. Simple non-invasive method to obtain DNA for gene analysis. Lancet i: 1356-1358.

50. Marx, J.L. 1988. DNA fingerprinting takes the witness stand. Science 240: 1616-1618.

51. Weiss, R. 1989. DNA takes the stand. Science News 136: 74-76.

52. Touchette, N. 1990. Genes in good hands with insurers? /. Natl. Inst. Health Res. 2: 37.

53. Andrews, L.B. 1991. Law and the crystal ball: Legal aspects of medical genetics. Yale /. Med. 69: 29-40.

54. Xiao, X., M. Cao, T.R. Miller, Z.-Y. Cao, and T.S.B. Yen. 1988. Papillomavirus DNA in cervical carcinoma specimens from central China. Lancet ii: 902.

55. Kwok, S. and J.J. Sninsky. 1989. Application of PCR to the detection of human infectious diseases. In PCR technology-Principles and applications for DNA amplification (ed. H.A. Erlich), pp. 235-244. Stockton Press, New York.

56. Brisson-Noel, A., B. Gicquel, D. Lecossier, V. Levy-Frebault, X. Nassif, and A.J. Hance. 1989. Rapid diagnosis of tuberculosis by amplification of mycobacterial DNA in clinical samples. Lancet ii: 1069-1071.

57. Barker, R.H., T. Banchongaksorn, J.M. Courval, W. Suwankerd, K. Rimwangtrakgul, and D.F. Wirth, personal communication.

58. Dennis, J.A., P.J. Healy, A.L. Beaudet, W.E. O'Brien. 1989. Molecular definition of bovine argininosuccinate synthetase deficiency. Proc. Natl.
Acad. Sci. 86: 7947-7951.

59. Healy, P.J., P.A. Harper, and J.A. Dennis. 1990. Bovine citrullinaemia: A clinical, pathological, biochemical and genetic study. Aust. Vet. J. 67: 255-258.

60. McCabe, E.R.B. 1991. Genetic screening for the next decade: Application of present and new technologies. Yale J. Med. 64:9-14.

61. Schwartz, E.I., S.E. Khalchitsky, R.C. Eisensmith, and S.L.C. Woo. 1990. Polymerase chain reaction amplification from dried blood spots on Guthrie cards. Lancet ii: 639-640.

62. Gibbs, R.A., P.N. Nguyen, and C.T. Caskey. 1989. Detection of single base differences by competitive oligonucleotide priming. Nucleic Acids Res. 17: 2437-2448.

63. Chehab, F.F. and Y.W. Kan. 1990. Detection of sickle cell anemia mutation by colour amplification. Lancet i: 15-17.

64. Landegren, U., R. Kaiser, C.T. Caskey, and L. Hood. 1988. DNA diagnostics-Molecular techniques and automation. Science 242: 229-237.

65. Kemp, D.J., D.B. Smith, S.J. Foote, N. Samaras, and M.G. Peterson. 1989. Colorimetric detection of specific DNA segments amplified by polymerase chain reactions. Proc. Natl. Acad. Sci. 86: 2423-2427.

66. Nickerson, D.A., R. Kaiser, S. Lappin, J. Steward, L. Hood, and U. Landegren. 1990. Automated DNA diagnostics using an ELISA-based oligonucleotide ligation assay. Proc. Natl. Acad. Sci. 87: 8923-8927. 


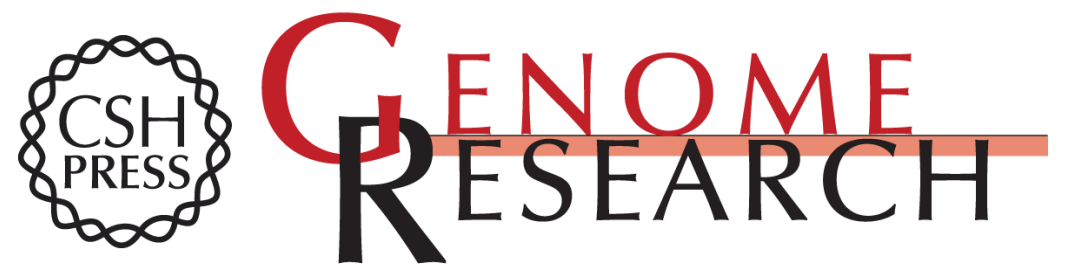

\section{Utility of PCR for DNA analysis from dried blood spots on filter paper blotters.}

E R McCabe

Genome Res. 1991 1: 99-106

Access the most recent version at doi:10.1101/gr.1.2.99

References This article cites 43 articles, 11 of which can be accessed free at:

http://genome.cshlp.org/content/1/2/99.full.html\#ref-list-1

\section{License}

Email Alerting Receive free email alerts when new articles cite this article - sign up in the box at the Service top right corner of the article or click here.

\section{Affordable, Accurate Sequencing.}

To subscribe to Genome Research go to: https://genome.cshlp.org/subscriptions 